\title{
Villafranchian large mammals from the Iberian Peninsula: paleobiogeography, paleoecology and dispersal events
}

\author{
J. Madurell-Malapeira',*, S. Ros-Montoya², M.P. Espigares², D.M. Alba ${ }^{1}$, J. Aurell-Garrido ${ }^{1}$ \\ ${ }^{1}$ Institut Català de Paleontologia Miquel Crusafont, Universitat Autònoma de Barcelona. Edifici ICP, Campus de la UAB s/n, \\ 08193 Cerdanyola del Vallès, Barcelona, Spain. \\ ${ }^{2}$ Museo Municipal de Prehistoria y Paleontología, Calle Tiendas, sn, 18858 Orce, Granada, Spain. \\ e-mail addresses: joan.madurell@icp.cat,(J.M.-M., *corresponding author),sergiorosm@gmail.com (S.R.-M.),mpespigares@gmail.com (M.P.E); \\ david.alba@icp.cat (D.M.A.), josep.aurell@icp.cat (J.A.-G.)
}

Received: 27 July 2013 / Accepted: 5 December 2013 / Available online: 25 February 2014

\begin{abstract}
The Pleistocene of the Iberian Peninsula is currently a focus of intense paleontological, archaeological and geological research. To a large extent, these inquiries are intended to decipher the ecological factors that might have conditioned early Homo dispersals into the European continent during the late Early Pleistocene. In this respect, the research carried out during the last twenty years in several areas of the Iberian Peninsula (the Guadix-Baza Basin, the Sierra de Atapuerca, the Vallparadís Section and the Banyoles-Besalú Basin) have yielded a large amount of new significant data. Here we review such data and provide for the first time a comprehensive synthesis from a faunal, geological and paleoecological perspectives, by focusing on the relationship between paleoenvironmental conditions and early human dispersals during the late Early Pleistocene in the Iberian Peninsula. In particular, the Iberian fossil record of Early to Late Villafranchian large mammals is synthesized, on the basis of recent publications and unpublished data collected by the authors during the last five years, in order to provide the adequate faunal and paleocological framework for understanding the factors that limited or conditioned human dispersal events.

Keywords: Mammals, Pliocene, Pleistocene, Villafranchian, Iberian Peninsula

\section{Resumen}

El Pleistoceno de la Península Ibérica es actualmente foco de intensa investigación paleontológica, arqueológica y geológica. En gran medida, estos trabajos están encaminados a descifrar los factores ecológicos que podrían haber condicionado las dispersiones de los Homo iniciales hacia Europa durante el Pleistoceno inferior. En este sentido, la investigación realizada durante los últimos veinte años en diversas zonas de la Península Ibérica (la Cuenca de Guadix-Baza, la Sierra de Atapuerca, la Sección de Vallparadís y la Cuenca de BanyolesBesalú) ha proporcionado una gran cantidad de nuevos datos significativos. Aquí revisamos estos datos y se proporciona por primera vez una síntesis exhaustiva desde una perspectiva paleontológica, paleoecológica y geológica, centrándonos en las relaciones entre las condiciones paleoambientales y las dispersiones de los primeros humanos en el Pleistoceno inferior de la Península Ibérica. Concretamente, se sintetiza el registro fósil ibérico de grandes mamíferos villafranquienses en base a publicaciones recientes y datos inéditos recopilados por los autores en los últimos cinco años, para así proporcionar el marco faunístico y paleoecológico adecuado para comprender los factores que limitaron o condicionaron los eventos de dispersión humana.
\end{abstract}

Palabras clave: Mamíferos, Plioceno, Pleistoceno, Villafranquiense, Península Ibérica

\section{Introduction}

The Villafranchian is a European large mammal biochronologic unit first introduced by Pareto (1865) as a continental stage referred to fluvial and lacustrine sediments in the surroundings of Villafranca d'Asti (Piedmont, Italy). During most of the past century, the Villafranchian was considered the first stage of the continental Pleistocene (Rook and Mar-
tínez-Navarro, 2010). Nevertheless, several authors pointed that the so-called Villafranchian faunas were not homogeneous (Azzaroli, 1962, 1970). Nowadays the Villafranchian is divided into three different stages: the Early Villafranchian (Late Pliocene, ca. 3.6-2.6 Ma), the Middle Villafranchian (Early Pleistocene, ca. 2.6-1.8 Ma) and the Late Villafranchian (Early Pleistocene, ca. 1.8-1.1 Ma). According to some scholars, next to the Villafranchian it would follow the 
Galerian biochronologic unit (late Early and early Middle Pleistocene, ca. 1.1-0.4 Ma; Palombo et al., 2008; Rook and Martínez-Navarro, 2010). However, the latest Villafranchian and the earliest Galerian correspond in fact to a transitional time interval, in which several Villafranchian species persisted and some Galerian newcomers were first recorded in Europe. This transitional unit (ca. 1.1-0.78 Ma) was named Epivillafranchian by Bourdier (1962).

Historically, Villafranchian faunas have been identified in the Iberian Peninsula from several localities-such as Villarroya (La Rioja), La Puebla de Valverde (Teruel), Cova Bonica (Barcelona) and Begur-2 (Girona), among othersthanks to the pioneering works of Miquel Crusafont-Pairó and Josep F. de Villalta (Villalta, 1952; Kurtén and CrusafontPairó, 1977). Later, in the 1980s and 1990s, numerous field surveys led by Josep Gibert and Emiliano Aguirre resulted in the discovery of various new localities in the Guadix-Baza Basin and the Sierra de Atapuerca (Aguirre et al., 1987; Gibert, 1992), among others. These works, still ongoing, were mainly focused on studying the paleoecological conditions and faunal context that probably limited or conditioned the dispersal of first hominin populations into Europe.

Here, we provide an updated synthesis of Villafranchian and Epivillafranchian localities from the Iberian Peninsula, on the basis of recently publications as well as unpublished data collected by the authors in the last five years. This review is intended to provide the adequate faunal and paleocological framework necessary for understanding the factors that limited or conditioned human dispersal events into the Iberian Peninsula during the Pleistocene.

\section{Paleoenvironmental background}

The Late Pliocene and the Pleistocene were characterized by great climatic shifts, as well as by changes in the orbital cycles that conditioned the periodicity of the glacial cycles. Several recent works have dealt with the consequences of these climatic changes on the Villafranchian and Galerian large mammal communities (Palombo, 2007, 2010; Kahlke et al., 2011; Magri and Palombo, 2013). These works have shown that large mammals respond to these changing environmental circumstances in several ways, including the appearance of new species (as a consequence of local evolution or dispersal events) as well as changes in their distribution areas, following the latitudinal changes experienced by the vegetal cover and the biome as a whole (Palombo, 2007; Madurell-Malapeira, 2010). Throughout the Villafranchian, two main faunal turnovers took place among large mammal communities: the oldest one corresponds to the transition between the Early and the Middle Villafranchian (ca. 2.6 Ma), whereas the youngest corresponds to the Early to Middle Pleistocene boundary (ca. $0.78 \mathrm{Ma}$ ). These two faunal renewals were followed by short time intervals of community restructuring, in which smaller changes also took place (Agustí and Antón,
2002; Palombo, 2007, 2010; Rook and Martínez-Navarro, 2010; Magri and Palombo, in press).

\subsection{Early Villafranchian}

At the beginning of the Villafranchian (ca. 3.6 Ma), environmental conditions remained warm and humid, as in the preceding Ruscinian (ca. 5.3-3.6 Ma). Nevertheless, at 3.2 $\mathrm{Ma}$, a glacial phase began in the Northern Hemisphere. This initial glacial pulse was associated to the first development of an ice cover in Greenland and the first aridity pulse in the Sahara. At the same time, a series of climatic shifts occurred in the Mediterranean area, being associated to the establishment of the modern Mediterranean climate, with warm and dry summers, temperate winters and humid springs and autumns (Agustí and Antón, 2002). After this first glacial pulse, an important increase in temperature occurred, with mean temperatures in the Mediterranean area being about $5{ }^{\circ} \mathrm{C}$ higher than today (Lisiecki and Raymo, 2005; Bertini, 2010).

\subsection{Middle Villafranchian}

The Pliocene-Pleistocene boundary (ca. 2.6 Ma; MIS104) marks the beginning of new climatic conditions that definitively departed from the Pliocene climatic optimum. The Earth and, especially, the Northern Hemisphere entered in a new bipolar dynamics of extensive glaciations, with glacial periods alternated with interglacial periods, modulated in cycles of 41,000 years (Clarck et al., 2006). Although these first glacial pulses were less intense than the hard pulses characteristic of the Late Pleistocene, they caused significant changes in the ecosystems of middle and high latitudes. Most significantly, this glacial pulse that occurred at 2.6 Ma caused the first replacement of dense wooded areas by open landscapes similar to the tundra in Central and Northern Europe (Bertini, 2010).

\subsection{Late Villafranchian}

The Gelasian-Calabrian boundary (ca. 1.8 Ma) represents the beginning of another cold phase; in fact, several strong glacial pulses have been documented in the marine isotopic record (MIS70; Lisiecki and Raymo, 2005). In the Mediterranean area, such climatic instability is documented by alternations between wooded environments and open tundralike landscapes (Bertini, 2010). Finally, the disappearance of tropical ecosystems and their replacement by deciduous forests occured around 1.2 Ma, at the ending of the Late Villafranchian (Combourieu-Nebout, 1993, 1995).

\subsection{Epivillafranchian}

The latest Early Pleistocene is characterized by the beginning of a new episode in Earth history, called the Mid- 




Fig. 1.- Main Villafranchian and Epivillafranchian localities from the Iberian Peninsula discussed in the text, in biochronological order (see legend in the figure). Epivillafranchian: 1, Vallparadís Estació Middle Unit (layers EVT6, EVT7 and EVT8): 2, Cal Guardiola Upper Unit (layers D4, D5, D6, D7); 3, Vallparadís Estació Lower Unit (layers EVT10, EVT11 and EVT12). Late Villafranchian: 4, Cueva Victoria; 5, Pontón de la Oliva, Cueva de los Huesos; 6, Bòvila Ordis; 7, El Chaparral; 8, Quibas; 9, Cal Guardiola Lower Unit (layers D1, D2 and D3); 10, Sima del Elefante (TE9); 11, Fuente Nueva-3; 12, Cortijo las Sabinas; 13, Barranco León 5; 14, Incarcal Site complex (including IN-I, IN-II and IN-V); 15, Venta Micena; 16, Fuensanta del Júcar; 17, Begur-2; 18, Barranco del Paso; 19, Algoz; 20, Avenc Marcel; 21, El Provencio; 22, Cortes de Baza; 23, Villanueva de Pítamo; 24, Puerto Real; 25, Chipiona; 26, Barranco de los Conejos. Middle Villafranchian: 27, Láchar; 28, Fonelas P-1; 29, Almenara-Casablanca-1; 30, Huélago; 31, La Puebla de Valverde; 32, Zújar-14; 33, Valdeganga III; 34, Fuente Nueva-2; 35, Fuente Nueva-1. Early Villafranchian: 36, Villarroya; 37, Zújar-11; 38, Valverde de Calatrava II; 39, Las Higueruelas; 40, El Rincón-1; 41, Cova Bonica; 42, Almenara-Casablanca-4; 43, Pantano de Cubillas; 44, Pozo de Piedrabuena; 45, La Puebla de Almoradier; 46, Valdeganga I and II; 47, Cova de l'Embarcador del Francès. Unknown age: 48, Canal Negre 1.

Pleistocene Transition or Middle Pleistocene Revolution (MPR), which elapsed from 1.25 Ma to the early Middle Pleistocene (ca. 0.7 Ma) (Maslin and Ridgwell, 2005; Clarck et al., 2006), rather coinciding with the Epivillafranchian biochron (ca. 1.1-0.78 Ma). The low-amplitude, $41 \mathrm{ka}$ obliquity-forced climate cycles characteristic of the late Early Pleistocene were replaced progressively by high-amplitude, $100 \mathrm{ka}$ cycles. The later cycles implied a transition towards a strongly non-linear forced climate system, and were accompanied by a substantial increase in global ice volume at $0.94 \mathrm{Ma}$ (Maslin and Ridgwell, 2005). These climate changes, particularly the increasing severity and duration of cold stages, had a profound effect on the biota and the physical landscape, especially in the Northern Hemisphere. During this period of instability, MIS 22 (ca. 0.88-0.87 Ma) was the most severe glacial pulse. Nevertheless, the effects of this glacial stage were probably milder in lower latitudes (the Iberian and Italian Peninsulas) than in Central Europe (Madurell-Malapeira et al., 2010a). For example, in the
Bòvila Ordis section (Porqueres, Girona, Iberian Peninsula), the pollen record evidences that the MIS22 did not imply marked changes in the vegetation cover (Suc and Popescu, 2005). Moreover, climatic conditions during the preceding MIS21 were probably the most favorable during the whole MPR (Almogi-Labin, 2011).

\section{The Iberian record of Villafranchian large mammals}

\subsection{Early Villafranchian}

The most significant Early Villafranchian Iberian localities are Villarroya (La Rioja), Las Higueruelas (Ciudad Real) and Rincón-1 (Albacete) (Fig. 1; Villalta, 1952; Alberdi et al., 1997; Mazo et al., 2003). These sites record the persistence of some taxa of humid-forest affinities that were already recorded in the Late Ruscinian of Europe, such as Anancus arvernensis. On the other hand, several new taxa made their first appearance in Iberia at that time, including: taxa 
more adapted to wooded savannahs and open areas, such as Mammuthus meridionalis, Stephanorhinus etruscus, Equus livenzovensis and E. stenonis; the pursuit predators Acinonyx pardinensis and Homotherium latidens; the ambush predators Meganteron cultridens, Lynx issiodorensis, Nyctereutes megamastoides, Pliocrocuta perrieri and Chasmaporthetes lunensis; and the extinct badger Meles thorali (MadurellMalapeira, 2010). The record of Mammuthus and Equus slightly before the Early-Middle Villafranchian boundary is particularly noteworthy. In the past, this so-called 'ElephantEquus event' was linked to the onset of the glacial dynamics at 2.6 Ma (Azzaroli, 1977). These taxa are apparently first recorded in the Dacic Basin in Romania in the case of Mammuthus, and in the French locality of Vialette in the case of Equus (Lacombat et al., 2008; Markov and Spassov, 2003). With regard to artiodactyls, Gazella borbonica and Gazelospira torticornis, characteristic of the Middle Villafranchian assemblages, are first recorded in the Iberian Peninsula in localities such as La Puebla de Almoradier, Pozo de Piedrabuena, el Rincón-1 and Las Higueruelas (Alberdi et al., 1997; Mazo et al., 2003; Andrés and DeMiguel, 2008). As far as carnivorans are concerned, the record of Megantereon cultridens and Meles thorali at Villarroya and Almenara-Casablanca 4 apparently represents the first record of these taxa in Europe, suggesting that by this time these species might have been already distributed throughout this continent (Palmqvist et al., 2007; Madurell-Malapeira et al., 2009a, 2011a,b). Finally, is also noteworthy the first record in the Iberian Peninsula of the cercopithecid Paradolichopithecus at Cova Bonica (Barcelona) (Moyà-Solà et al., 1990).

\subsection{Middle Villafranchian}

The post Gauss large mammal faunas from the Iberian Peninsula are well-known since the late 1960s, when the first field surveys were carried out at La Puebla de Valverde (Teruel) by a team led by Miquel Crusafont-Pairó (Crusafont-Pairó et al., 1964; Heintz et al., 1971; Kurtén and Crusafont-Pairó, 1977). During the last decade, the field work carried out at Fonelas P-1 (Granada) has significantly increased our current knowledge on the Middle Villafranchian faunas from Iberia (Arribas, 2008). The estimated age of La Puebla de Valverde is 2.14-1.95 Ma, whereas that of Fonelas P-1 is close to 2.0 Ma (Sinusía et al., 2004; Arribas, 2008). As such, both localities only record the latest Middle Villafranchian. In contrast, Huélago (Granada) possibly records the earliest Middle Villafranchian faunas from the Iberian Peninsula, being correlated to the Italian Montopoli faunal unit (ca. 2.5-2.3 Ma; Alberdi et al., 2001).

The faunal assemblages from the localities of La Puebla de Valverde, Fonelas P-1 and Almenara-Casablanca 1 (Castelló) record a large number of first appearance data, not only for the Iberian Peninsula, but also in many instances for Europe as a whole. Thus, the remains of the giant short-faced hyena Pachycrocuta brevirostris from Fonelas and Almenara-
Casablanca 1 are the first occurrences of this species in Europe, otherwise well known from the Olivola Faunal Unit onwards (Rook and Martínez-Navarro, 2010). The Iberian record therefore puts back the so-called 'Pachycrocuta event' before the beginning of the Olduvai magnetostratigraphic chron (Arribas, 2008; Martínez-Navarro, 2010). Moreover, a revision of the carnivoran remains from La Puebla de Valverde enables to discount the presence of Lycaon falconeri, previously cited by Kurtén and Crusafont-Pairó (1977) in this locality on the basis of a decidual upper premolar that probably belongs to a hyaenid. Additionally, we recognized for the first time in Europe the presence of Panthera gombaszoegensis in pre-Olduvai layers (J.M.M.'s unpublished data), previously only tentatively identified in the Bulgarian site of Slivnitsa (ca. 1.9-1.8 Ma, Kahlke et al., 2011). On the other hand, the presence of the middle-sized felid Puma pardoides is also recognized in La Puebla de Valverde, corresponding to a primitive form of this species, closer to the specimens from Saint-Vallier (Madurell-Malapeira et al., 2010b). Among the carnivorans, it is also significant the presence of Canis etruscus and the surprising record of Hyaena brunnea in Fonelas P-1 (Arribas, 2008). Finally, the presence in Fonelas P-1 of artiodactyls of African origin, such as Potamochoerus and Mitilanotherium, in addition to the above-mentioned newcomers Panthera gombaszoegensis, Hyaena brunnea and Pachycrocuta brevirostris, opens a new, as yet unresolved debate concerning the faunal dispersals that took place during the Middle Villafranchian in relation to the establishment of the glacial/interglacial dynamics (Arribas et al., 2009).

\subsection{Late Villafranchian}

The Iberian Peninsula has plenty of well-known Late Villafranchian localities, including the following (Figs. 1 and 2): Venta Micena (1.6-1.4 Ma, Granada; Palmqvist et al., 2005); the Incarcal site complex (ca. 1.5 Ma, Girona; Galobart and Maroto, 2003; Ros-Montoya et al., 2012); Barranco León and Fuente Nueva 3 (1.4-1.2 Ma, Granada; MartínezNavarro et al., 2010); Sima del Elefante (ca. 1.2 Ma, Burgos; Carbonell et al., 2008); the Lower Unit of the Cal Guardiola local section (ca. 1.2 Ma, Barcelona; Madurell-Malapeira et al., 2010a); and Quibas (ca. 1.3-1.0 Ma, Murcia; Montoya et al., 2001).

The beginning of the Late Villafranchian represents a major faunal renewal, which involved the extinction of several species (most of them herbivores) as well as the arrival of several new forms of Asian and African origin. Several taxa with a long record during the Villafranchian, such as Stephanorhinus etruscus, Equus stenonis, Gazellospira, Gazella, Cervus phillisi, Arvernoceros ardei and Croizetoceros ramosus, vanished from the Iberian Peninsula around the Middle-Late Villafranchian boundary. These taxa were replaced by newcoming species, most of them of Asian origin, namely Stephanorhinus hundsheimensis, Equus altidens, Praemegaceros verticornis, Hemibos, Hemitragus and Soergelia minor (Fig. 


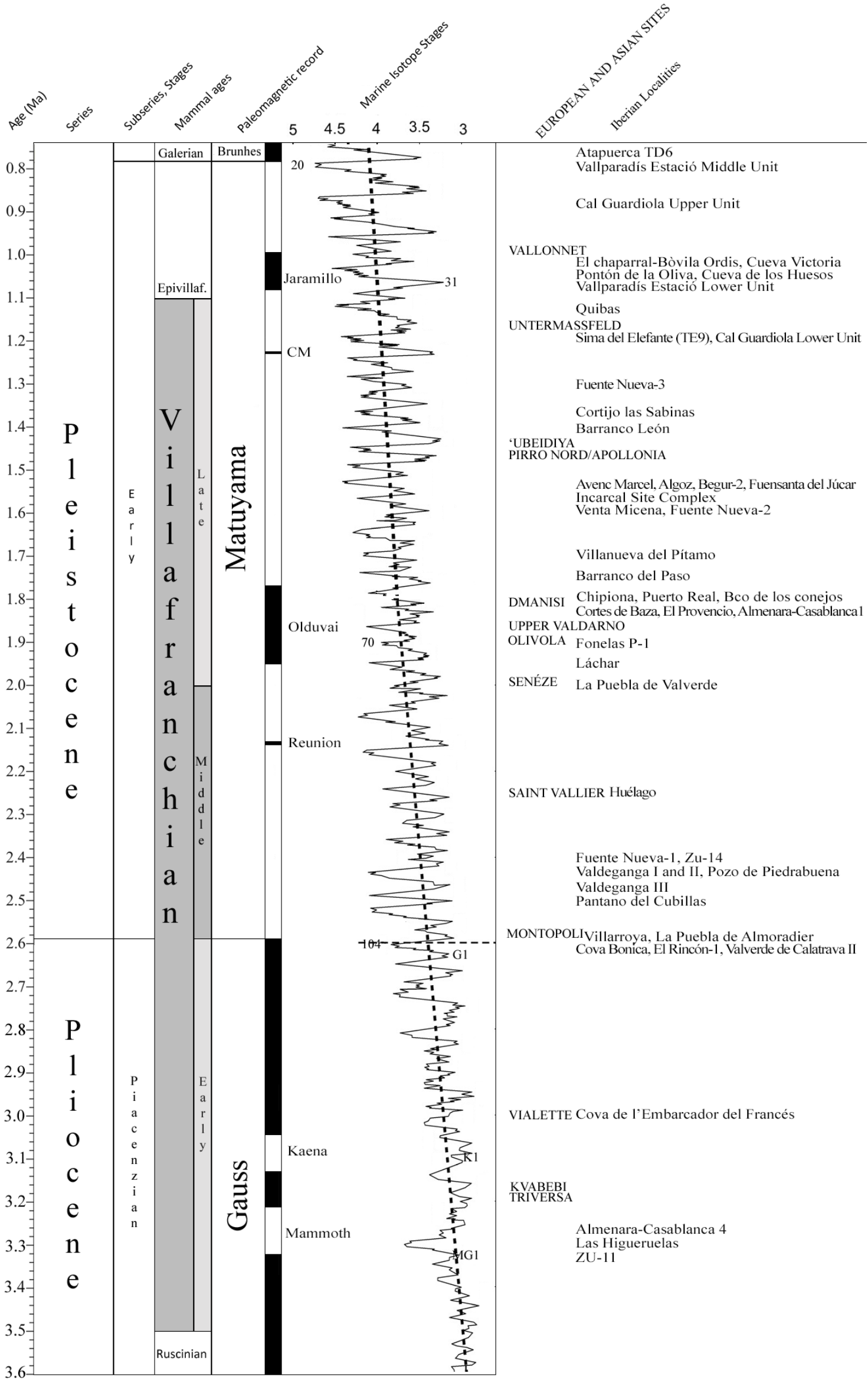

Fig. 2.- Correlation of the Villafranchian and Epivillafranchian Iberian localities with the geomagnetic polarity time scale. 


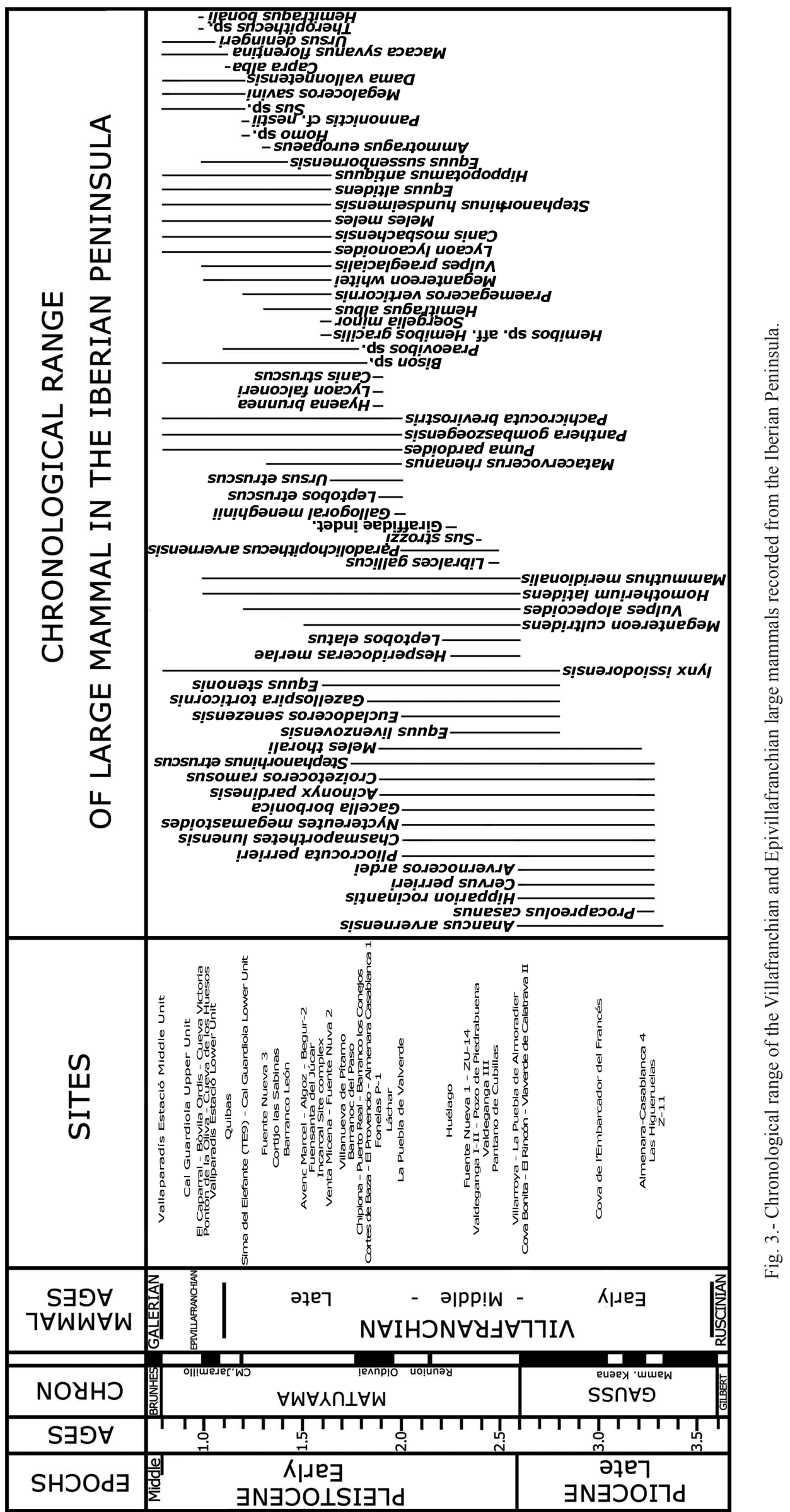


3, SI), most of them being first recorded at Venta Micena (ca. 1.6-1.4 Ma; Palmqvist et al., 2005). Regarding carnivorans, in Iberia several Middle Villafranchian species did not survive the transition into the Late Villafranchian and its associated climatic shifts, including Megantereon cultridens, Acinonyx pardinensis, Pliocrocuta perrieri, Chasmaportetes lunensis, Lycaon falconeri, Nyctereutes megamastoides and Meles thorali.

The locality of Venta Micena, representing the best-known site of the first stage of the Late Villafranchian in Iberia, records even more important first Iberian occurrences of several species, such as the large hippo Hippopotamus antiquus, the dirk-toothed cat Megantereon whitei, the pack-hunting canid Lycaon lycaonoides, and the wolf-like dog Canis mosbachensis (Palmqvist et al., 2005; Martínez-Navarro, 2010 and references therein; Fig. 3).

Slightly after the Allophaiomys ruffoi biozone (ca. 1.6-1.4 $\mathrm{Ma}$ ), which includes the localities of Venta Micena and Incarcal, evidences from the earliest Iberian hominins are recorded in Barranco León and Fuente Nueva 3 (only lithic artifacts; Palmqvist et al., 2005), as well as in Sima del Elefante (skeletical remains; Carbonell et al., 2008). This earliest record of the presence of hominins in the Iberian Peninsula is associated with the arrival of several new species, including the bovid Ammotragus europaeus (presumably occupying the same ecological niche as the vanished Soergelia minor), the large horse Equus suessenbornensis, and the extant badger Meles meles, all of them being first recorded in the Guadix-Baza Basin (Martínez-Navarro et al., 2010; Madurell-Malapeira et al., 2011b). In turn, the typically Galerian genera Megaloceros and Dama are first recorded in the lower layers of the Cal Guardiola local section (J.M.M.'s unpublished data; Fig. 3, SI).

\subsection{Epivillafranchian}

The Iberian record of Epivillafranchian large mammal faunas is also well known, the main Iberian localities being Cueva Victoria (1.0 Ma, Murcia; Blain et al., 2008), El Chaparral (ca. 1.0 Ma, Cadiz; Pacheco et al., 2011) and the different layers of the Vallparadís section (1.0-0.83 Ma, Barcelona; Madurell-Malapeira et al., 2010a). These sites record the last faunas of Villafranchian character of southwestern Europe, being associated with several typically Galerian/Aurelian lineages, such as Sus, Megaloceros and Dama (Fig. 3). It is also noteworthy the presence at Cueva Victoria of the large cercopithecid Theropithecus (Gibert et al., 1995). Among the last appearance data, Cueva Victoria site and Vallparadís Estació layer 10 record the latest occurrences of Megantereon whitei in Europe, whereas Vallparadís Estació layer 7 last records Pachycrocuta brevirostris, Lycaon lycaonoides and Puma pardoides in Europe (Madurell-Malapeira et al., 2010a).

It is also worth-mentioning the intense current debate on the origins of the cave and brown bear lineages. Several authors have concluded that the specimens from Gran Dolina
TDW4 (ca. 0.9 Ma, Burgos), together with those from the Vallonnet Cave (1.0 Ma, France) and Deutch-Altenburg (ca. 1.4 Ma, Austria), represent the oldest European brown bears (García and Arsuaga, 2001; García, 2003; Moullé, 2005; Olive, 2006; Rabeder et al., 2010). However, the Vallparadís ursid remains, coming from layers CGRD5, EVT10, EVT7 and EVT6 (ca. 1.0-0.83 Ma), display all the known range of morphologic variability of Epivillafranchian bears from elsewhere in Europe, further showing several craniodental features derived towards the cave bear lineage (Madurell-Malapeira et al., 2009b, 2010a, 2011c). It seems therefore much more likely that all the European latest Late Villafranchian and Epivillafranchian bears do belong in fact to the cave bear linage. Accordingly, all of these specimens are here tentatively attributed to Ursus deningeri (Madurell-Malapeira et $a l ., 2011 \mathrm{c})$, awaiting a detailed revision of the available fossil remains.

Finally, it is also noticeable that, from the latest Villafranchian of Sima del Elefante until the earliest Galerian of Gran Dolina TD6, human presence is not clearly recorded in the Iberian Peninsula. Lithic tools were recently reported from layer 7 of the Vallparadís Estació local section (Martínez et al., 2010), but the anthropic origin of such remains has been questioned on the basis of geologic and taphonomic evidence (Madurell-Malaperia et al., 2012).

\section{Discussion}

An updated summary of Villafranchian large mammal taxa and localities in the Iberian Peninsula is reported here, based on the revision of more than 100 bibliographic references, as well as on the basis of authors' unpublished data. A total of 48 different localities are reported from the whole Iberian Peninsula, 13 from the Early Villafranchian, 10 from the Middle Villafranchian, 18 from the Late Villafranchian, 5 from the Epivillafranchian and one with an undetermined age. This information is summarized in figs. 2 and 3 and in the online supplementary material, which show the chronological position of all the localities and the ranges of the different Iberian Villafranchian large mammals.

\subsection{Villafranchian faunal dynamics}

The Iberian Peninsula displays a good record of Villafranchian and Epivillafranchian large mammal faunas, similar to that from other parts of southwestern Europe, such as Italy and France (Palombo and Valli, 2003; Rook and Martínez-Navarro, 2010). Nevertheless, the Iberian record is not continuous through the several stages of the Villafranchian, which might bias the interpretations of the available record. In contrast, the data from the latest Villafranchian and Epivillafranchian localities of the Iberian Peninsula are excellent. Currently available data from the Iberian Peninsula (Fig. 3) show two main periods of faunal renewal, including speciation and extinction of several species, followed by the arrival 
of new forms (mainly of Asian and African origin). These two events, previously identified in several works concerning the large mammal faunas of France and Italy, perfectly fit the timing of the two main climatic shifts experienced by European ecosystems during the Pleistocene. The first one corresponds to the Early to Middle Villafranchian transition at $2.6 \mathrm{Ma}$, coinciding with the onset of the glacial dynamics, whereas the second corresponds to the Epivillafranchian (ca. 1.1-0.78 Ma), being related to the climatic instability associated with the 'Mid-Pleistocene Revolution' (Madurell-Malapeira, 2010; Rook and Martínez-Navarro, 2010; Magri and Palombo, 2013).

Certainly, the disappearance of several taxa from the record, as well as the appearance of new-coming taxa, do not seem to have been strictly synchronous across Europe. For example, in the Iberian Peninsula the Middle to Late Villafranchian turnover seems to have happened earlier than in the rest of Europe, further displaying additional differences, including the earliest record of several genera, such as Hyaena, Potamochoerus and Mitilanotherium. Similarly, in Iberia several Villafranchian taxa persisted until de Early-Middle Pleistocene boundary (P. pardoides, L. lycaonoides, P. brevirostris), whereas several Galerian species (C. crocuta, Ce. elaphus) were also first recorded there (Madurell-Malapeira et al., 2010a).

Available data (Fig. 3, SI) show that the Iberian record of Villafranchian large mammals displays two main points of renewal. First, an initial phase of restructuring of the large mammal assemblages occurred synchronously with the onset of glacial dynamics, resulting in important changes in the mammalian communities. At that time, tropical elements disappeared and new species appeared by showing a great unexpected diversity, especially in the latest Middle Villafranchian, where Hyaena, Pachycrocuta, P. gombaszoegensis, Potamochoerus and Mitilanotherium were recorded within an environment dominated by warm Artemisa steppes and woodland areas (Suc et al., 1995). A second stage of restructuring of the mammalian Iberian assemblages was associated to the 'Mid-Pleistocene Revolution', during which the long-lasting Villafranchian species coexisted with several new-coming, typically Galerian forms. In the Iberian Peninsula, Villafranchian forms survived the MIS22, persisting until the MIS21 (ca. $0.83 \mathrm{Ma}$ ). The pollen data from northeastern Iberian Peninsula show no remarkable changes in vegetation cover during the MIS22 (Suc and Popescu, 2005). Nevertheless, slightly later during the Early-Middle Pleistocene transition, a decrease in the diversity of plant species is recorded in northeastern Iberia and southern France (Magri and Palombo, 2013, Fig. 2; Pastre et al., 2007; Julià and Suc, 1980; Albin, 1991).

To sum up, the data summarized above show that the Iberian large mammal assemblages experienced two major stages of renewal during the Villafranchian, like in the rest of Europe, although the timing of these renewals was not strictly synchronous throughout Mediterranean Europe.

\subsection{Iberian Late Villafranchian/Early Galerian carnivorans} and early hominin dispersals

The oldest evidence of hominin presence in the Iberian Peninsula comes from three localities (Barranco León, Fuente Nueva 3 and Sima del Elefante) from the latest Late Villafranchian (ca. 1.4-1.2 Ma; Palmqvist et al., 2005; Carbonell et al., 2008; Martínez-Navarro et al., 2010). In the Iberian Peninsula, this time interval was characterized by warm temperatures and no great climatic shifts, with landscapes dominated by open dry grasslands and several wooded areas (Leroy et al., 2011). Several authors suggested that the paleoenvironmental conditions most favorable for the dispersal of hominins across Europe would correspond to open landscapes, similar to the African environments where early Homo had evolved. The Iberian Peninsula apparently displayed such kind of environments, although other factors might have conditioned the survival of these early Homo populations. In particular, taphonomic studies carried out in the Orce localities suggest that large carnivorans, such as Pachycrocuta, were responsible of an intense bone modification activity during the Early Pleistocene. Evidences of early Homo modification are also recorded, although the analysis of available data has thus far suggested a primary access to the carcasses only under occasional circumstances (Echassoux, 2004; Huguet, 2007; Espigares, 2010). It is not possible to compare this situation with that in other European sites of the same age where human presence has been recorded, such as Pirro Nord (Italy, ca. 1.6-1.4 Ma; Arzarello et al., 2007), Lézignan-le-Cèbe (France, $1.57 \mathrm{Ma}$; Crochet et al., 2009), Pont de Lavaud (France, 1.2-1.1 Ma; Despriée et al., 2006), Terre-des-Sablons (France, ca. 1.2 Ma; Despriée et al., 2010) and Kozarnika Cave (Bulgaria, ca. 1.6-1.4 Ma; Sirakov et al., 2010), because no detailed taphonomic studies have been to date carried out in these localities. The data from the somewhat younger (Galerian, ca. 0.9 Ma) TD6 layer of the Gran Dolina in Atapuerca (Moreno-García, 2011) show that, at this site, early humans had early access to the carcasses (Díez et al., 1999), although it should be taken into account that this site corresponds to a protected karstic environment, instead of an open landscape as in Orce.

With regard to the role played by carnivorans as a limiting factor for early Homo dispersals in the Iberian Peninsula, the Late Villafranchian Iberian carnivore assemblage is more or less composed by the same species as in southwestern Europe, with the only exception of Acinonyx pardinensis, which is not recorded in the Iberian Late Villafranchian (Palombo and Valli, 2003; Rook and Martínez-Navarro, 2010). The absence of the large Villafranchian cheetah in Iberia is probably artifactual, resulting from the incompleteness of the record. In any case, large Villafranchian carnivorans persist in the Iberian Peninsula until the MIS21, i.e. slightly later than in the other European localities, with the only exception of Slivia (Italy), where P. brevirostris is recorded close to the Early-Middle Pleistocene boundary (Palombo et al., 2008). 
The long persistence of Villafranchian large carnivores in the Iberian and Italian Peninsulas is probably related to the lesser impact that the climatic shifts of the 'Mid-Pleistocene Revolution' had in the lower latitudes of Mediterranean areas as compared to Central Europe.

A parallelism can be established between the composition of the carnivoran guild and the impact of hominin activities in the record. Thus, in the localities with Villafranchian carnivorans, hominin activities have a much scarcer impact than in the localities with Galerian carnivorans such as Crocuta crocuta, Panthera pardus and Panthera leo (Madurell-Malapeira, 2010; Madurell-Malapeira et al., 2010a; 2012). Moreover, once the MPR has finished and all the Galerian carnivorans are recorded in Europe, Acheulian stone tools are first recorded in the Mediterranean area (Madurell-Malapeira, 2010; Martínez-Navarro, 2010). The key site for evaluating the relationship between the composition of the carnivoran guild and human activity is Gran Dolina TD6, which first records several Galerian species (such as Crocuta and Cervus elaphus) and further displays the oldest evidence of primary access to the carcasses in Europe (Díez et al., 1999; García and Arsuaga, 1999; Van der Made, 1999). Traditionally, TD6 has been interpreted as very close in age to the Early-Middle Pleistocene boundary (ca. $0.78 \mathrm{Ma}$ ); under this interpretation, the presence of Crocuta would not be surprising. However, new ESR datings suggest that the age of TD6 is closer to $0.9 \mathrm{Ma}$, whereas TD4 would be very close to the Jaramillo subchron (MorenoGarcía, 2011). These new chronological background implies the coexistence in time of Pachycrocuta (recorded in EVT7 of the Vallparadís section ca. $0.83 \mathrm{Ma}$ ) with Crocuta (recorded in TD4 and TD6, ca. 0.95-0.90 Ma) during the latest Early Pleistocene of the Iberian Peninsula. This should not be surprising, since the coexistence of these two hyenids is well documented for more than one million years in East Africa (Werdelin and Lewis, 2005). Incidentally, it should be noted that the record of Crocuta in layers close to the Jaramillo subchron reopens the debate on the taxonomic identity of the two medium to large felid first lower molars from the Vallonnet Cave (France, ca. $1.0 \mathrm{Ma})$. These specimens were attributed to Panthera pardus by Moullé (1992) and Moullé et al. (2006), and to Puma pardoides by Hemmer (2001). A recent description of the Iberian specimens of Puma-like cats (Madurell-Malapeira et al., $2010 \mathrm{~b}$ ) as well as the study of the large collections of Panthera pardus from the Royal Museum for Central Africa (Tervuren, Belgium; J.M.M.'s unpublished data) indicates that the Vallonnet molars, as previously suggested by Moullé et al. (2006; contra Hemmer, 2001), correspond to the oldest record of Panthera pardus in Europe. If this is correct, it implies the dispersal of several African carnivoran species (the leopard and spotted hyena) into Europe prior to the MIS22 (ca. $0.88 \mathrm{Ma}$ ).

The evidence provided by carnivorans further agrees with some studies of the early human remains from the Iberian Peninsula. Thus, Bermúdez de Castro et al. (2011) recently suggested that the human mandible from Sima del Elefante differs in some regards from the Gran Dolina TD6 material custom- arily attributed to Homo antecessor (Bermúdez de Castro et al., 2008, 2011). As a result, Bermúdez de Castro et al. (2011) merely attribute the Sima del Elefante mandible to Homo sp., further suggesting that the populations from these two localities might correspond to two different hominin taxa (Bermúdez de Castro et al., 2011), one from pre-Jaramillo times and the other from post-Jaramillo ones (Fig. 2). The younger population would probably result from a second dispersal event, probably across the Levantine corridor (Bermúdez de Castro and Martinón-Torres, in press). This second wave of hominin dispersal, either from Africa or the Levantine Corridor, would be related to the presence of Crocuta and Panthera pardus in the layers of Gran Dolina and Vallonnet, which agrees with the record of Crocuta at 1.4 Ma in Ubeidiya (Israel; MartínezNavarro et al., 2009).

\section{Conclusions}

The data summarized here evidence the occurrence of two main faunal renewals in the Villafranchian of the Iberian Peninsula. These renewals, the first one during the latest Middle Villafranchian (ca. 2.0 Ma) and the second one during the Epivillafranchian (ca. 1.1-0.78 Ma), were not strictly synchronous with those in the rest of the Europe. Available data from the Late Villafranchian and Epivillafranchian localities of the Iberian Peninsula further suggest two different steps in hominin dispersal in this area. The first wave of dispersal would correspond to the latest Late Villafranchian, in paleoenvironments dominated by open dry grasslands and several wooded areas, and being associated to several other incoming species, mainly of Asian origin, such as Ammotragus europaeus or Equus sussenbornensis. These human populations, however, would have still coexisted with the large Villafranchian carnivorans and, as a result, would have had a lesser impact on the taphocenosis. The second human dispersal event, beginning more or less at the same time than the MPR and somewhat before the great climatic shifts that took place at $0.9 \mathrm{Ma}$, would have probably involved the arrival of new hominin populations from Africa or the Levantine corridor. These human populations would have been associated to the latest Villafranchian carnivorans, which in the Iberian Peninsula survived longer than in Central Europe due to more favorable climatic conditions, but also to the African newcomers, Crocuta and Panthera pardus, having a greater impact on the taphocenosis.

\section{Acknowledgements}

This work has been supported by the Spanish Ministerio de Ciencia e Innovación (CGL2011-28681, and RYC-200904533 to D.M.A.) and the Generalitat de Catalunya (2009 SGR 754 GRC). We sincerely thank M. Nebot, L. Rook, R. D. Kahlke, G. Koufos, L. Werdelin, R. Patnaik, K. Holekamp, E. Swanson, B. Van Valkenburgh, R. Croitor, K. Seymour, P. E. Moullé, E. Gilissen and W. Wendelen for providing information, useful papers and access to the collections under their care. 


\section{References}

Aguirre, E., Carbonell, E., Bermúdez de Castro, J. M. (1987): El Hombre fósil de Ibeas y el Pleistoceno de la Sierra de Atapuerca. I. Junta de Castilla y León, Consejería de Cultura y Bienestar Social: 439 p.

Agustí, J., Antón, M. (2002): Mammoths, Sabretooths and Hominids: 65 Million Years of Mammalian Evolution in Europe. Columbia University Press, New York, 311 p.

Alberdi, M.T., Cerdeño, E., López-Martínez, N., Morales, J., Soria, D. (1997); La fauna Villafranquiense de El Rincón-1 (Albacete, CastillaLa Mancha). Estudios Geológicos 53, 69-93.

Alberdi, M.T., Alonso, M.A., Azanza, B., Hoyos, M., Morales, J. (2001): Vertebrate taphonomy in the circum-lake environments: three cases in the Guadix-Baza Basin (Granada, Spain). Palaeo 165, 1-26.

Albin, D. (1991): Analyse pollinique des dépots lacustres de Ceyssac, Plio-Pléistocène du Velay (Massif central, France). Cahiers de Micropaléontologie 6, 21-38.

Almogi-Labin, A. (2011): The paleoclimate of the Eastern Mediterranean during the transition from Early to Mid Pleistocene $(900$ to $700 \mathrm{ka}$ ) based on marine and nonemarine records: an integrated overview. Journal of Human Evolution 60, 428-436. doi: 10.1016/j. jhevol.2010.03.007

Andrés, M., DeMiguel, D. (2008): Registro del género Gazella en el Neógeno español. Stvdia Geologica Salmanticensia 8, 17-26.

Arribas, A. (2008): Vertebrados del Plioceno superior terminal en el suroeste de Europa: Fonelas P-1 y el Proyecto Fonelas. Instituto Geológico y Minero de España, serie Cuadernos del Museo Geominero $10,607 \mathrm{p}$.

Arribas, A., Garrido, G., Viseras, C., Soria, J.M., Pla, S., Solano, J.G., Garcés, M., Beamud, E., Carrión, J.S. (2009): A mammalian lost world in Southwest Europe during the Late Pliocene. PloS ONE 4, e7127. doi: 10.1371/journal.pone.0007127.

Arzarello, M., Marcolini, F., Pavia, G., Pavia, M., Petronio, C., Petrucci, M., Rook, L., R. Sardella. (2007): Evidence of earliest human occupation in Europe: the site of Pirro Nord (Southern Italy). Naturwissenschaften 94, 107-112. doi: 10.1007/s00114-006-0173-3.

Azzaroli, A. (1962): Rinoceronti Pliocenici del Valdarno Inferiore. Palaeontographia Italica 57, 11-20.

Azzaroli, A. (1970): Villafranchian correlations based on large mammals. Giornale di Geologia 35, 111-131.

Azzaroli, A. (1977): The Villafranchian stage in Italy and the Plio-Pleistocene boundary. Giornale di Geologia 41, 61-79.

Bermúdez de Castro, J.M, Martinón-Torres, M. (2013): A new model for the evolution of the human Pleistocene populations of Europe. Quaternary International 295, 102-111. doi: 10.1016/j.quaint.2012.02.036

Bermúdez de Castro, J.M., Pérez-González, A., Martinón-Torres, M., Gómez- Robles, A., Rosell, J., Prado, L., Sarmiento, S., Carbonell, E. (2008): A new Early Pleistocene hominin mandible from AtapuercaTD6, Spain. Journal of Human Evolution 54, 118-124. doi: 10.1016/j. jhevol.2008.03.006

Bermúdez de Castro, J.M., Martinón-Torres, M., Gómez-Robles, A., Prado-Simón, L., Martín-Francés, L., Lapresa, M., Olejniczak, A., Carbonell, E. (2011): Early Pleistocene human mandible from Sima del Elefante (TE) cave site in Sierra de Atapuerca (Spain): A comparative morphological study. Journal of Human Evolution 161, 1-11. doi: 10.1016/j.jhevol.2011.03.005.

Bertini, A. (2010): Pliocene to Pleistocene palynoflora and vegetation in Italy: State of the art. Quaternary International 225, 5-24. doi: 10.1016/j.quaint.2010.04.025.

Blain, H.A, Bailon, S., Agusti, J. (2008): Amphibians and squamate reptiles from the latest early Pleistocene of Cueva Victoria (Murcia, southeastern Spain, SW Mediterranean): paleobiogeographic and paleoclimatic implications. Geologica Acta 6, 345-361. doi: 10.1344/105.000000262.

Bourdier, F. (1962): Le bassin du Rhône au Quaternaire. Géologie et
Préhistoire. C.N.R.S., Paris, tome I: 364 p., tome II: 294 p.

Carbonell, E., Bermúdez de Castro, J.M., Parés, J.M., Pérez-González, A., Cuenca-Bescós, G., Ollé, A., Mosquera, M., Huguet, R., van der Made, J., Rosas, A., Sala, R., Vallverdú, J., García, N., Granger, D.E., Martinón-Torres, M., Rodríguez, X.P., Stock, G.M., Vergès, J.M., Allué, E., Burjachs, F., Cáceres, I., Canals, A., Benito, A., Díez, C., Lozano, M., Mateos, A., Navazo, M., Rodríguez, J., Rosell, J., Arsuaga, J.L. (2008): The first hominin of Europe. Nature 452, 465469. doi: $10.1038 /$ nature 06815 .

Clark, P., Archer, D., Pollard, D., Blum, J.D., Rial, J.A., Brovkin, V., Mix, A.C., Pisias, N.G., Roy, R. (2006): The Middle Pleistocene transition: characteristics, mechanisms, and implications for longterm changes in atmospheric pCO2. Quaternary Science Reviews 25, 3150-3184. doi: 10.1016/j.quascirev.2006.07.008.

Combourieu-Nebout, N. (1993): Vegetation response to upper Pliocene glacial/interglacial cyclicity in the central Mediterranean. Quaternary Research 40, 228-236.

Combourieu-Nebout, N. (1995): Réponse de la végétation de l'Italie méridionale au seuil climatique de la fin du Pliocène d'après l'analyse pollinique haute résolution de la section de Semaforo (2,46 à 2.1 Ma). Comptes Rendus de l'Academie des Sciences Paris 321, 659-665.

Crochet, J.Y., Welcomme, J.L., Ivorra, J., Ruffet, G., Boulbes, N., Capdevila, R., Claude, J., Firmat, C., Metais, G., Michaux, J., Pickford, M. (2009): Une nouvelle faune de vertébrés continentaux, associée à des artefacts dans le Pléistocène inférieur de l'Hérault (Sud de la France), vers 1,57 Ma. Comptes Rendus Palevol 8, 725-736. doi: 10.1016/j.crpv.2009.06.004.

Crusafont Pairó, M., Hartenberger, J.L, Heintz, E. (1964): Un nouveau gisement de Mammifères fossiles d'âge villafranchien à La Puebla de Valverde (Province de Teruel, Espagne). Comptes Rendus de l'Academie des Sciences Paris 258, 2869-2871.

Díez, J.C., Fernández-Jalvo, Y., Rosell, J., Cáceres, I. (1999): Zooarcheology and taphonomy of Aurora Stratum (Gran Dolina, Sierra de Atapuerca, Spain). Journal of Human Evolution 37, 623-652. doi: 10.1006/jhev.1999.0346.

Despriée, J., Gageonnet, R., Voinchet, P., Bahain, J.J., Falguères, C., Varache, F. (2006): Une occupation humaine au Pléistocène inférieur sur la bordure nord du Massif Central. Comptes Rendus Paleovol 5, 821-828. doi: 10.1016/j.crpv.2006.03.001.

Despriée, J., Voinchet, P., Tissoux, H., Moncel, M. H., Arzarello, M., Robin, S., Bahain, J. J., Falguères, C., Courcimault, G., Dépont, J., Gageonnet, R., Marquer, L., Messager, E., Abdessadok, S., Puauda, S. (2010): Lower and Middle Pleistocene human settlements in the Middle Loire River Basin, Centre Region, France. Quaternary International 223-224, 345-359. doi: 10.1016/j.quaint.2009.07.019.

Echassoux, A. (2004): Étude taphonomique, paléoécologique et archéozoologique des faunes de grands mammifères de la seconde moitié du Pléistocène inférieur de la grotte du Vallonnet (Roquebrune-CapMartin, Alpes-Maritimes, France). L'Anthropologie 108, 11-53. doi: 10.1016/j.anthro.2004.01.006.

Espigares, M.P. (2010): Análisis y Modelización del Contexto Sedimentario y los Atributos Tafonómicos de los Yacimientos Pleistocénicos del borde Nororiental de la Cuenca de Guadix-Baza. Ph.D. dissertation, Universidad de Granada, Granada.

Galobart, Á., Maroto, J. (2003): Los yacimientos paleotológicos de Incarcal (Crespià). Palentologia i Evolució 34, 224 p.

García, N. (2003): Osos y otros carnívoros de la sierra de Atapuerca. Fundación Oso de Asturias, Oviedo.

García, N., Arsuaga, J.L. (1999): Carnivores from the Early Pleistocene hominid-bearing Trinchera Dolina 6 (Sierra de Atapuerca, Spain). Journal of Human Evolution 37, 415-430. doi: 10.1006/ jhev.1999.0325.

García, N., Arsuaga, J.L. (2001): Ursus dolinensis: a new species of Early Pleistocene ursid from Trinchera Dolina, Atapuerca (Spain). Comptes Rendus de l'Academie des Sciences Paris 332, 717-725. 
doi: 10.1016/S1251-8050(01)01588-9.

Gibert, J. (1992): Proyecto Orce-Cueva Victoria (1988-1992): Presencia humana en el Pleistoceno interior de Granada y Murcia. Ayuntamiento de Orce (Granada), Museo de Prehistoria "J. Gibert" Granada, $354 \mathrm{p}$.

Gibert, J., Ribot, F., Gibert, L., Leakey, M., Arribas, A., Martínez, B. (1995): Presence of the cercopithecid genus Theropithecus in Cueva Victoria (Murcia, Spain). Journal of Human Evolution 28, 487-493. doi: 10.1006/jhev.1995.1036.

Heintz, E., Delson, E., Crusafont Pairó, M. (1971): Descubrimiento del género Macaca en el yacimiento de La Puebla de Valverde (Teruel). Boletín Real Sociedad Española Historia Natural 69, 299-302.

Hemmer, H. (2001): Die Feliden aus dem Epivillafranchium von Untermassfeld.. In: R. D. Kahlke (ed.), Das Pleistozän von Untermassfeld bei Meiningen (Thüringen), Römisch-Germaisches Zentralmuseum, Bonn, 699-782.

Huguet R. (2007): Primeras ocupaciones humanas en la Península Ibérica: paleoeconomía en la Sierra de Atapuerca (Burgos) y en la Cuenca de Guadix-Baza (Granada) durante el Pleistoceno Inferior. Ph.D. dissertation, Universitat Rovira i Virgili, 601 p.

Julià, R., Suc, J.P. (1980): Analyse pollinique des dépôts lacustres du Pléistocène Inférieur de Banyoles (Bañolas, site de la Bòbila OrdisEspagne): un élément nouveau dans la reconstitution de l'histoire paléoclimatique des régions méditerranéennes d'Europe Occidentale. Geobios 13, 5-19. doi: 10.1016/S0016-6995(80)80012-X.

Kahlke, R.D., García, N., Kostopoulos, D.S., Lacombat, F., Lister, A.M., Mazza, P.P.A., Spassov, N., Titov, V. (2011): Western Palaearctic palaeoenvironmental conditions during the Early and early Middle Pleistocene inferred from large mammal communities, and implications for hominin dispersal in Europe. Quaternary Science Reviews 30, 1368-1395. doi: 10.1016/j.quascirev.2010.07.020.

Kurtén, B., Crusafont-Pairó, M. (1977): Villafranchian carnivores (Mammalia) from La Puebla de Valverde (Teruel, Spain). Commentationes Biologicae 85, 1-39.

Lacombat, F., Abbazzi, L., Ferreti, M., Martinez-Navarro, B., Moullé, P.E., Palombo, M.R., Rook, L., Turner, A., Valli, A.M.F. (2008): New data on the Early Villafranchian fauna from Vialette (Haute-Loire, France). Collection of the Crozatier museum (Le Puy-en-Velay, Haute-Loire. France). Quaternary International 179, 64-71. doi: 10.1016/j.quaint.2007.09.005.

Leroy, S.A.G., Arpe, K., Mikolajewicz, U. (2011): Vegetation context and climatic limits of the Early Pleistocene hominin dispersal in Europe. Quaternary Science Reviews 30, 1448-1463. doi: 10.1016/j. quascirev.2010.01.017.

Lisiecki, L.E., Raymo, M.E. (2005): A Pliocene-Pleistocene stack of 57 globally distributed benthic $\delta 180$ records. Paleoceanography 20 , 1-17. doi: 10.1029/2004PA001071.

Madurell-Malapeira, J. (2010): The Villafranchian carnivores from the North-Eastern Iberian Peninsula and the Early-Middle Pleistocene Transition. Unpublished Ph. D. Thesis, Universitat Autònoma de Barcelona.

Madurell-Malapeira, J., Santos-Cubedo, A., Marmi, J. (2009a): Oldest ocurrence of Meles (Mustelidae, Carnivora) from the Middle Pliocene (MN16) of Almenara-Casablanca-4 karstic site (Castellón, Spain). Journal of Vertebrate Paleontology 29, 961-965. doi: 10.1671/039.029.0322.

Madurell-Malapeira, J., Alba, D. M., Moyà-Solà, S. (2009b): Carnivora from the late Early Pleistocene of Cal Guardiola (Terrassa, VallèsPendès Basin, Catalonia, Spain). Journal of Paleontology 83, 969 974. doi: 0022-3360/09/0083-0969\$03.00.

Madurell-Malapeira, J., Minwer-Barakat, R., Alba, D.M., Garcés, M., Gómez, M., Aurell-Garrido, J., Ros-Montoya, S., Moyà-Solà, S., Berástegui, X. (2010a): The Vallparadís section (Terrassa, Iberian Peninsula) and the latest Villafranchian faunas of Europe. Journal of Quaternary Science Reviews 29, 2972-2982. doi: 10.1016/j. quascirev.2010.09.020

Madurell-Malapeira, J., Alba, D.M., Moyà-Solà, S., Aurell-Garrido, J. (2010b): The Iberian record of the puma-like cat Puma pardoides (Carnivora, Felidae). Comptes Rendus Palevol 9, 55-62. doi: 10.1016/j.crpv.2009.12.002.

Madurell-Malapeira, J., Alba, D.M., Marmi, J., Aurell, J., Moyà-Solà, S. (2011a): The taxonomic status of European Plio-Pleistocene badgers. Journal of Vertebrate Paleontology 31, 885-894. doi: 10.1080/02724634.2011.589484.

Madurell-Malapeira, J., Martínez-Navarro, B., Ros-Montoya, S., Espigares, M.P., Palmqvist, P. (2011b): The earliest European badger (Meles meles), from the Late Villafranchian site of Fuente Nueva-3 (Orce, Granada, SE Iberian Peninsula). Comptes Rendus Palevol 10, 609615. doi: 10.1016/j.crpv.2011.06.001.

Madurell-Malapeira, J., Fortuny, J., Alba, D.M., Aurell-Garrido, J., Moyà-Solà, S. (2011c): Early steps towards the Cave Bear Lineage. $17^{\text {th }}$ Cave Bear Symposium, Hertz (Germany), Abstracts book, 23-24.

Madurell-Malapeira, J., Alba, D.M., Minwer-Barakat, R., Aurell-Garrido, J., Moyà-Solà, S. (2012): Early human dispersals into the Iberian Peninsula: A comment on Martínez et al. (2010) and Garcia et al. (2011). Journal of Human Evolution 62, 169-173. doi:10.1016/j. jhevol.2011.10.005.

Magri, D., Palombo, M.R. (2013): Early to Middle Pleistocene dynamics of plant and mammal communities in South West Europe. Quaternary International 288, 63-72, doi: 10.1016/j.quaint.2012.02.028.

Markov, G.N., Spassov, N. (2003): Primitive mammoths from Northeast Bulgaria in the context of the earliest mammoth migrations in Europe.. In A. Petulescu and E. Stiuca (eds.), Advances in Vertebrate Palaeontology Hen to Pantha. Institut of Speleology of the Romanian Academy, Bucharest, 53-58.

Martínez, K., Garcia, J., Carbonell, E., Agustí, J., Bahain, J.J., Blain, H.A., Burjachs, F., Cáceres, I., Duval, M., Falguères, C., Gómez, M., Huguet, R. (2010): A new Lower Pleistocene archeological site in Europe (Vallparadís, Barcelona, Spain). Proceedings of the $\mathrm{Na}$ tional Academy of Sciences, U.S.A. 107, 5762-5767. doi:10.1073/ pnas.0913856107.

Martínez-Navarro, B. (2010): Early Pleistocene faunas of Eurasia and hominid dispersals. In J. G. Fleagle, J. J. Shea, F. E. Grine, A. L. Baden, and R. E. Leakey (eds.), Out of Africa I: Who? When? and Where? Springer, Dordrecht, 207-224.

Martínez-Navarro, B., Belmaker, M., Bar-Yosef, O. (2009): The large carnivores from 'Ubeidiya (early Pleistocene, Israel): biochronological and biogeographical implications. Journal of Human Evolution 56, 514-524. doi: 10.1016/j.jhevol.2009.02.004.

Martínez-Navarro, B., Palmqvist, P., Madurell-Malapeira, J., Ros-Montoya, S., Espigares, M.P., Torregrosa, V., Pérez-Clarós, J.A. (2010): La fauna de grandes mamíferos de Fuente Nueva 3 y Barranco León 5. Estado de la cuestión. In: Toro, I., Martínez-Navarro, B., Agustí, J. (Eds), Ocupaciones Humanas en el Pleistoceno Inferior y Medio de la Cuenca de Guadix-Baza, Memoria Cientifica. Junta de Andalucía. Consejería de Cultura. E.P.G. Arqueología Monográfico, 197-236.

Maslin, M. A., Ridgwell, A. J. (2005): Mid-Pleistocene revolution and the 'eccentricity myth'. In M. J. Head and P. L. Gibbard (eds.), Early Middle Pleistocene Transitions: The Land Ocean Evidence. Geological Society, London, Special Publication, 19-34.

Mazo, A.V., van der Made, J., Arribas, A., Sánchez, A. (2003): Catálogo de la exposición «Hace tres millones de años», Museo Provincial de Ciudad Real. Ed. Fundación Cultura y Deporte de Castilla-La Mancha y Junta de Comunidades de Castilla-La Mancha, 53 p.

Montoya, P., Alberdi, M.T., Barbadillo, L.J., Van der Made, J., Morales, J., Murelaga, X., Peñalver, E., Robles, F., Ruiz-Bustos, A., Sánchez, A., Sanchiz, B., Soria, D., Szyndlar, Z. (2001): Une faune très diversifiée du Pléistocène inférieur de la Sierra de Quibas (provincia de Murcia, Espagne). Comptes Rendus de l'Académie des Sciences París 332, 387-393. doi: 10.1016/S1251-8050(01)01544-0. 
Moreno-García, D. (2011): Datation par ESR de quartz optiquement blanchis (ESR-OB) de la région de Atapuerca (Burgos, Espagne). Application au site préhistorique de Gran Dolina (contexte karstique) et aux systèmes fluviatiles quaternaires de l'Arlanzón et l'Arlanza. Unpublished Ph. D. Thesis, Universitat Rovira i Virgili, Tarragona, Spain, $305 \mathrm{p}$.

Moullé, P.E. (1992). Les grands mammifères du Pléistocene inférieur de la grotte du Vallonnet (Roquebrune-Cap-Martín, Alpes Maritimes). Étude paléontologique des Carnivores, Equidé, Suidé et Bovidés. Ph.D. dissertation, Muséum National d'Histoire Naturelle, Paris.

Moullé, P.E. (2005): Le Pléistocène inférieur, le Villafranchien supérieur. La faune du Velay entre 1,8 et 1 million d'années: Ursus sp. In: F. Lacombat (ed.), Les grands mammifères fossiles du Velay. Les collections paléontologiques du Plio-Pléistocène du musée Crozatier - Le Puy-en-Velay. Annales des Amis du musée Crozatier 13-14, 82-83.

Moullé, P.E., Lacombat, F., Echassoux, E. (2006): Apport des grands mammifères de la grotte du Vallonnet (Roquebrune-Cap-Martin,AlpesMaritimes, France) à la connaissance du cadre biochronologique de la seconde moitié du Pléistocène inférieur d'Europe. L'Anthropologie 110, 837-849. doi: 10.1016/j.anthro.2006.10.006.

Moyà Solà, S., Pons Moyà, J., Köhler, M. (1990): Primates catarrinos (Mammalia) del Neógeno de la península Ibérica. Paleontologia i Evolució 23, 41-45.

Olive, F. 2006: Évolution des grands Carnivores au Plio Pléistocene en Afrique et en Europe occidentale. L'Anthropologie 110, 850-869. doi: 10.1016/j.anthro.2006.10.005.

Pacheco, F.G., Santiago, A., Gutiérrez, J.M., López-García, J.M., Blain, H.A., G., Cuenca-Bescós, Van Der Made, J., Cáceres, I., García, N. (2011): The Early Pleistocene paleontologial site in the Sierra del Chaparral (Villaluenga del Rosario, Cádiz, Southwestern Spain). Quaternary Internatinal 24, 92-104. doi: 10.1016/j.quaint.2011.05.034.

Palmqvist, P., Martínez-Navarro, B., Toro, I., Espigares, M.P., Ros-Montoya, S., Torregrosa, V., Pérez-Clarós, J.A. (2005): A re-evaluation of the evidence of human presence during Early Pleistocene times in southeastern Spain. L'Anthropologie 109, 411-450. doi: 10.1016/j. anthro.2005.06.001.

Palmqvist, P., Torregrosa, V., Pérez-Claros, J.A., Martínez-Navarro, B., Turner, A. (2007): A re-evaluation of the diversity of Megantereon (Mammalia, Carnivora, Machairodontinae) and the problem of species identification in extinct carnivores. Journal of Vertebrate Paleontology 27, 160-175.

Palombo, M.R. (2007): The Early to Middle Pleistocene faunal revolution. Quaternary International 167-168, 105-124.

Palombo, M.R. (2010): A scenario of human dispersal in the northwestern Mediterranean throughout the Early to Middle Pleistocene. Quaternary International 223-224,179-194. doi: 10.1016/j. quaint.2009.11.016.

Palombo, M. R., Valli, A.F.M. (2003): Biochronology of large mammal faunas from Pliocene to Middle Plestocene in France. Geologica Romana 37, 145-163.

Palombo, M. R., Sardella, R., Novelli, M. (2008): Carnivora dispersal in Western Mediterraenan during the last 2.6 Ma. Quaternary International 179, 72-78. doi: 10.1016/j.quaint.2007.08.029.
Pareto, M. (1865): Sur les subdivisions que l'on pourrait établir dans les terraines Tertiaires de l'Apennin septentrional. Bulletin de la Société Géologique de France 22, 210-277.

Pastre, J. F., Gauthier, A., Nomade, S., Orth, P., Andrieu, A., Goupille, F., Guillou, H., Kunesch, S., Scaillet, S., Renne, P.R. (2007): The Alleret maar (Massif Central, France): a new lacustrine sequence of the early Middle Pleistocene in western Europe. C. R. Geoscience 339, 987-997. doi: 10.1016/j.crte.2007.09.019.

Rabeder, G., Pacher, M., Withalm, G. (2010): Early Pleistocene Bear remains from Deutch-Altenburg (Lower Austria). Mitteilungen der Kommission für Quartärforschung der Österreichischen Akademie der Wissenschaften, Band 17, Verlag der Österreichischen Akademie der Wissenschaften, Vienna, 116 p.

Rook, L., Martínez-Navarro, B. (2010) : Villafranchian: the long story of a Plio-Pleistocene European large mammal biochronologic unit. Quaternary International 219, 134-144. doi: 10.1016/j. quaint.2010.01.007.

Ros-Montoya, S., Madurell-Malapeira, J., Martínez-Navarro, B., Espigares, P., Palmqvist, P. (2012): Late Villafranchian Mammuthus meridionalis (Nesti, 1825) from the Iberian Peninsula: Dentognathic remains from Incarcal-I (Crespià, Girona) and Venta Micena (Orce, Granada). Quaternary International 276-277, 17-22, doi: 10.1016/j. quaint.2012.03.007

Sinusía, C., Pueyo, E.L., Azanza, B., Pocovi, A. (2004): Datación magnetoestratográfica del yacimiento de Puebla de Valverde (Teruel). Geotemas 6, 339-342.

Sirakov, N.L., Guadelli, J.L., Ivanova, S., Sirakova, S., Boudadi-Maligne, M., Dimitrova, I., Fernandez, P, Ferrier, C., Guadelli, A., Iordanova, D., Iordanova, N., Kovatcheva, M., Krumov, I., Leblanc, J., Miteva, V., Popov, V., Spassov, R., Taneva, S., Tsanova, T. (2010): An ancient continuous human presence in the Balkans and the beginnings of human settlement in western Eurasia: A Lower Pleistocene example of the Lower Palaeolithic levels in Kozarnika cave (North-western Bulgaria) Quaternary International 223-224, 94-106. doi: 10.1016/j. quaint.2010.02.023

Suc, J.P., Bertini, A., Combourieu-Nebout, N., Diniz, F., Leroy, S., Russo Ermolli, E., Zheng, Z., Bessais, E., Ferrier, J. (1995): Structure of west Mediterranean and climate since 5.3 Ma. Acta Zoologica Cracoviensia 38, 3-16.

Suc, J.P., Popescu, S.M. (2005): Pollen records and climatic cycles in the North Mediterranean region since 2.7 Ma. In: M. J. Head and E. L. Gibbard (eds.), Early-Middle Pleistocene Transitions: The LandOcean Evidence. Geological Society, London, Special Publications 247, 147-158.

van der Made, J. (1999): Ungulates from Atapuerca TD6. Journal of Human Evolution 37, 389-413. doi: 10.1006/jhev.1998.0264.

Villalta, J.F. (1952): Contribución al conocimiento de la fauna de mamíferos fósiles del Plioceno de Villarroya (Logroño). Boletín del Instituto Geológico y Minero de España 64, 1-203.

Werdelin, L., Lewis, M.E. (2005): Plio-Pleistocene Carnivora of eastern Africa: species richness and turnover patterns. Zoological Journal of the Linnean Society 144, 121-144. doi: 10.1111/j.10963642.2005.00165.x. 